Brandon Thompson, Dylan Richardson, Robert D. Vangundy, and A. Bruce Cahoon. Metabarcoding comparison of prokaryotic microbiomes from Appalachian karst caves to surface soils in southwest Virginia, USA. Journal of Cave and Karst Studies, v. 81, no. 4, p. 244-253. DOI:10.4311/2019MB0112

\title{
METABARCODING COMPARISON OF PROKARYOTIC MICROBIOMES FROM APPALACHIAN KARST CAVES TO SURFACE SOILS IN SOUTHWEST VIRGINIA, USA
}

\author{
Brandon Thompson, Dylan Richardson, Robert D. Vangundy, and A. Bruce Cahoon ${ }^{c}$
}

\begin{abstract}
Caves in carbonate rocks of the temperate Appalachian karst region of the United States host impressive ecosystems comprised of cave-adapted and endemic fauna. The primary source of biological energy to epigenic cave systems has been presumed to be surface-derived organic matter, however, the provenance of the prokaryotic microorganisms utilizing that organic matter is uncertain. Specifically, we sought to determine whether the microbes in these caves propagate from established subterranean communities, or rather, enter from the surface via infiltration and migration. This project addresses these overarching questions by determining a) significantly differing composition of prokaryotic communities inside the caves versus those found immediately outside; and b) similarity of the interior cave microbiomes between cave systems. Samples were collected from four caves in The Cedars area of Lee County VA and from two caves within Natural Tunnel State Park in Scott County, VA, and included cave sediments from streambeds, moist claysized deposits, and speleothems. Exterior soil samples were collected outside of the caves, with particular attention to sites of water infiltration into the caves below. Prokaryotic microbiomes were surveyed by Illumina sequencing the 16S rRNA barcode. Results detected 1894 unique operational taxonomic units (OTU), $21.4 \%$ of which were shared between cave speleothems and surface soil, while $53.8 \%$ of the OTU in cave sediment were also found in surface soil. The cave microbiomes had only small to moderate differences and were more similar to each other than to surface microbiomes. Of the phyla detected in this survey, two have not been reported in previous cave microbiome surveys, Armatimonadetes and Parvarchaeota. This survey demonstrates that the cave prokaryotic microbiomes in a temperate region with regular rainfall are primarily composed of cave-adapted microbes and that these microbes occur throughout independent cave systems in the same region.
\end{abstract}

\section{INTRODUCTION}

Caves are meteorologically stable environments with low temperature fluctuations, high humidity, and relatively neutral $\mathrm{pH}$. These conditions would make caves attractive to many biological organisms except for the extreme lack of primary energy input (e.g., light) that limits these biomes to oligotrophs - organisms adapted for survival in environments with extremely low nutrient content. Cave-dwelling oligotrophic prokaryotes have been formally studied for decades (e.g., Caumartin 1963, Barton and Northup 2007), and a combination of culturing and environmental DNA studies have found a large variety of microbes living in subterranean environments (e.g., Tomczyk-Żak and Zielenkiewicz 2016). Due to the lack of energy input, cave and soil microbes often live in biofilm communities and survive using metal oxidation or a variety of strategies such as nitrogen fixation, acquisition of volatilized aromatic compounds, or utilization of dissolved organic matter introduced via infiltrating meteoric water (Northup and Lavoie 2001; Ortiz et al., 2014). Communal lifestyles promote recycling of limited resources, such as the use of waste products excreted from other bacteria containing proteins, lipids, and other biomolecules (Barton et al., 2004, Barton et al., 2007). Certain bacteria form notable structures in caves such as pool fingers and moon milk, as they break down organic calcium salts and excrete calcium ions as waste products (Barton and Northup 2007). Still other microorganisms play a role in cave formation by mediating carbonate dissolution (e.g., Engel et al., 2004).

Since cave microbes are adapted to survive at the cusp of starvation and utilize numerous alternative energy acquisition strategies, the majority of them are difficult to culture and identify using traditional microbiological techniques. The advent of molecular genetic techniques for the identification of environmental DNA (eDNA) provides the potential to distinguish many microorganisms that have been overlooked using other methods (Torsvik and Øvreås, 2002). The first generation of molecular methodologies included PCR amplification of a marker gene followed by a host of fingerprinting methods (e.g., DGGE, RFLP, RAPD, RISA) and allowed an estimation of diversity, but without the benefit of taxonomic identifications (Dorigo et al., 2005). A newer approach, metabarcoding, provide marker sequences from a single genetic locus that can taxonomically distinguish microbial species. The first successful applications of metabarcoding utilized clone libraries of PCR amplicons and Sanger sequencing (Handelsman, 2004). Most recently, metabarcoding analyses have

Department of Natural Sciences, The University of Virginia's College at Wise, 1 College Ave., Wise, VA 24293

c Corresponding Author: abc6c@uvawise.edu 
been expanded to utilize next generation deep-sequencing technology enabling the identification of large numbers of microorganisms from many different environments (Wooley et al., 2010).

Metabarcoding coupled with next generation sequencing has been conducted in several caves, and operational taxonomic units OTU counts ranging from hundreds to thousands have been discovered on speleothems (Ortiz et al., 2013, Mendoza et al., 2016, Lavoie et al., 2017, Vardeh et al., 2018) and in sediment (De Mandal et al., 2017). There have been two notable outcomes from these studies. First, when cave interior microbes were compared to those of surface soils in two arid environments, very low overlapping OTU content was found - 16\% from Kartchner Caverns, AZ (Ortiz et al., 2013) and 11.2 \% from Lava Beds National Monument (Lavoie et al., 2017). Second, various cave micro-habitats harbored distinct microbiomes, irrelevant of their proximity to one another (Ortiz et al., 2013, Lavoie et al., 2017).

The purpose of this study was to perform a metabarcoding survey of the microbial communities from six caves found in the temperate Southern Appalachian Mountain range of North America with the intention of testing two hypotheses. Hypothesis 1 stated that caves in a temperate environment would share a larger proportion of microbes with the surface than caves in arid environments, and Hypothesis 2 stated that individual caves within a given karst ecosystem would exhibit insignificant differences in their microbiomes.

\section{Materials and Methods}

\section{Study Area and Sampling}

Samples were collected from 6 caves that developed in lower to middle Ordovician-aged carbonate rocks, located in southwestern Virginia (Miller and Brosge, 1954, Brent, 1963). Two of the caves, Bolling and Panel, are located within Natural Tunnel State Park in Scott County, VA. Both caves are gated and locked so human activity is limited to permitted researchers and guided tours conducted by park staff from May to October. Tours are conducted weekly during peak months (June-July) and monthly at non-peak times of year. Their entrances are $1.2 \mathrm{~km}$ apart and the two caves are hydrologically separated. Bolling Cave is located high on Copper Ridge on the western side of Stock Creek, roughly parallel to the north portal of Natural Tunnel. It has over $425 \mathrm{~m}$ of mapped passages. Infiltrating groundwater forms a small stream that exits the cave via a spring. Panel Cave is also situated in Copper Ridge, $1.2 \mathrm{~km}$ from the entrance of Bolling Cave, on the east side of Stock Creek, downstream from Natural Tunnel. It is a single meandering cavern approximately $190 \mathrm{~m}$ long. Panel Cave's stream is fed by infiltration from a sinking stream on the surface (unpublished dye trace data), and exits via a large spring. The remaining 4 caves, Smith's Milk, Gallohan $1 \& 2$, and Surgener, are located approximately $40 \mathrm{~km}$ from Natural Tunnel State Park in The Cedars Natural Preserve in Lee County, VA. This area was agricultural before its current designation as a natural preserve, and lands around the preserve are still farmed. These caves are not gated, but they occur on a combination of preserved and private land and are difficult to access. They are rarely visited, limited to sporadic tours by researchers and geology classes (once or twice a year), and the occasional trespasser. The four cave entrances occur within a $500 \mathrm{~m}$ radius and they are hydrologically connected with flow from Smith's Milk through Gallohan 2 and Gallohan 1, to Surgener (unpublished dye trace data). Recharge appears to be primarily, if not entirely, by surface infiltration of meteoric water. The cave stream exits Surgener through a large entrance and flows as a surface tributary to the Powell River. During periods of high river discharge, water can backflow to the entrance of Surgener Cave. Known animal occupants of all six caves are limited to several species of salamander, cave crickets, arachnids, and occasional bats during winter months (no large bat colonies have been observed). There is evidence of past bear activity in Bolling cave but no recent sightings.

Three types of samples were collected from each cave for microbiome analysis-speleothems or damp cave ceilings, cave sediments, and surface soils. Cave speleothems were sampled by rubbing sterile cotton swabs along the surfaces of damp formations, placing the cotton tip into a $1.5 \mathrm{~mL}$ microcentrifuge tube, and removing the wood handle with snips. Where no spelothems were present, samples were collected from damp cave ceilings. Sediments were collected by directly scooping substrate with an opened $15 \mathrm{~mL}$ sterile screw-cap conical tube and sealing the tube immediately after collection. The collected substrates ranged from small loose streambed gravel to sand or moist clay. Surface soils were collected from areas immediately outside of the cave entrances adjacent to the entrance pathway, as well as from areas overlying the caves wherever possible. Leaf litter was brushed away and top soil scooped into $15 \mathrm{~mL}$ sterile screw-cap tubes in a manner similar to the interior sediment sampling. All samples were transported in darkness to a laboratory at the University of Virginia's College at Wise and stored at $-20^{\circ} \mathrm{C}$ until further processing for DNA extraction. Three or more replicates of each type were collected from each site, and nitrile gloves were worn for all collections.

\section{DNA Extraction and Sequencing}

DNA was extracted from all soil and sediment samples using Qiagen's (Germantown, MD, USA) PowerSoil DNA Isolation kit following the manufacturer's instructions. DNA was extracted from the cotton swabs using the same kit with 
the following modification-swabs were placed directly into the bead-beater tubes as if they were soil samples. DNA samples were stored at $-20^{\circ} \mathrm{C}$. The $16 \mathrm{~S}$ rDNA V4 regions from all the replicates were PCR amplified during a GCATSEEK workshop (Genome Consortium for Active Teaching: https://gcat-seek.weebly.com) held at Hampton University (Hampton, VA) July 2017. The V4 rDNA regions were PCR amplified and prepared for multiplexed paired-end Illumina sequencing following the protocol of Caporaso et al. (2011). Paired-end deep sequencing was completed by Wright Labs LLC (Huntingdon, PA) using Illumina's MiSeq technology (reagents kit v2). The number of successfully sequenced replicates from each location and type is included in Table S1.

\section{OTU Clustering and Taxonomy Assignments}

A total of 4,070,451 raw sequences were produced from 49 samples. These were paired, trimmed, and quality filtered (expected error of $<0.5 \%$ ) using USEARCH version 7 (Edgar, 2010) leaving 101,719 sequences, representing 1894 unique OTU. Reads were analyzed with QIIME 1.9.0 software package (Caporaso et al., 2010). OTU were chosen and grouped from the quality filtered reads using UCLUST and singletons were discarded. OTU was defined as a group of reads with $\geq 97 \%$ similarity. Taxonomy was assigned using the Greengenes 16S rRNA gene database (release 135, DeSantis et al., 2006) and RDP Classifier (Wang et al., 2007).

\section{Alpha Diversity Analyses}

Replicate OTU data from each site and type were combined for all alpha diversity calculations (see Table S1 for number of completed replicates). Alpha diversity was estimated using Chao1 (Chao and Chiu 2016), Shannon (Smith and Wilson 1996), and Simpson (Pielou 1969) indexes calculated with the VEGAN package in R (Oksanen et al., 2018, R Core Team, 2018). Observed OTU represent the raw number of unique OTU from each site and type.

\section{Beta Diversity Analyses}

Comparisons between sample types and sites were conducted as multi-dimensional analyses. Principle Coordinates Analysis (PCoA) with scatter plots and Analysis of Similarity (ANOSIM) were conducted to compare the taxonomic compositions of each sample site. These were generated using identifiable OTU and their abundance with the software package PRIMER-E with the PERMANOVA add-on (Clark and Gorley, 2015). OTU counts were normalised with the square-root function and resemblance estimated using the Bray-Curtis index.

\section{Results}

\section{Cave Versus Surface Alpha Diversity}

A total of 1894 unique OTU were detected from the six sample sites; 1433 occurred within caves (482 from swabs and 1343 from sediment), and 1254 occurred in surface soil. Of these OTU, 1543 were taxonomically identifiable, with 1096 outside and 1174 inside; whereas, 640 OTU were found only in cave samples (Table S2).

Species richness and diversity estimates were calculated for the speleothems, cave sediments, and surface soil (Fig. 1, Supplemental Table S1). Surface soils and cave sediments exhibited the greatest richness according to observed values and Chao1 estimates, as well as the greatest diversities based on the Simpson and Shannon indices. Not only did cave sediments have the most abundant OTU, but the richness and diversity estimates demonstrated greater variability compared to soils outside the caves. Speleothem samples all had lower numbers of OTU than cave sediment or soil, but diversity estimates were much more variable, suggesting less consistency from sample to sample.

The OTU were organized by phylum, and relative abundance was calculated to determine differences between sample types (Table 1). The relative abundance of the most highly represented phyla was generally consistent between the exterior soil samples versus the cave sediments and speleothems. Differences were observed among the minor phyla; for example, Tenericutes was much less abundant in the speleothem samples versus outside soil and interior sediment, and seven phyla were not found on the speleothems. Two minor phyla were only observed inside the caves-NC10 and the Archaean, Crenarchaeota. The number of OTU with unassigned taxonomy was much larger among cave-specific sequences and several phyla had noticeably lower relative abundance in the cave-specific OTU. Two phyla, Armatimonadetes and the Archaean Parvarchaeota have not been previously reported to reside in caves.

\section{Cave Versus Surface OTU Comparison}

To determine the differences between the interiors and exterior environments of the six caves, we compared OTU observed on speleothems, exterior soil, and cave sediments (Fig. 2, Table S2). Each sample type was associated with unique OTU, and the cave sediments had the largest representation with 320 (Fig. 2A). Overall cave versus surface comparison shows that 1,133 of the 1894 OTU (59.8\%) were shared between the surface and subsurface. A comparison between the speleothem bacteria and surface soils show that 337 of 1574 OTU were shared (21.4\%). Comparisons between the cave sediments and exterior soils show that 904 OTU were shared (53.8\%) between the two environments. 

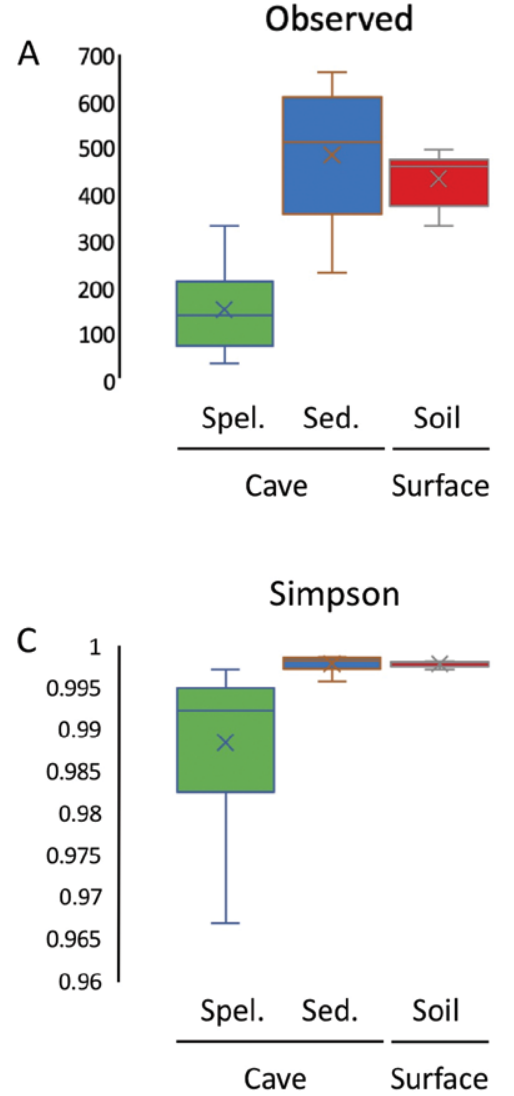
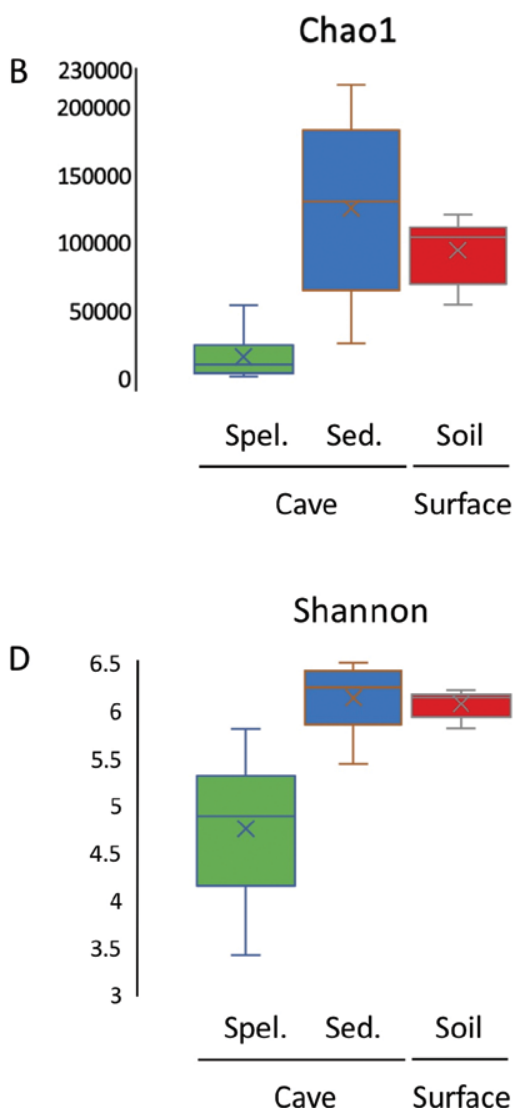

Figure 1. Box plots representing species richness and diversity estimates of the six caves sampled for this study. Species richness is represented as the number of unique observed operational taxonomic units (OTU) (A) and further estimated using the Chao1 (B), Simpson (C), and Shannon (D) indexes.

PCoA was completed for each replicate of each sample site and type (Fig. 2B). The exterior soil samples had the least amount of variation, with nearly all the replicates forming a distinct group. The interior sediment OTU were similar to exterior ones according to PCoA1 but dissimilar according to PCoA2. Cave sediment OTU were also much more variable than the exterior soil samples. Speleothem OTU were highly variable and overlapped very little with the sediment and soil samples.

Analysis of similarity (ANOSIM) was conducted to compare differences between the sample types. In overall comparisons, the largest significant $R$-value $(R=0.726, P=0.001)$, and thus, the greatest difference occurred between speleothem bacteria versus exterior soil. The second most significant difference occurred between speleothem versus cave sediment bacteria $(R=0.509, P$ $=0.001)$, and third, the significant difference between cave sediments and exterior soils was $R=0.23(P=0.001)$.

\section{Inter-cave Comparison}

OTU from the interiors of the six caves were compared to determine the similarities of microbiomes within different caves residing in the same region. Of the 1,598 OTU identified from cave interiors, 544 were unique to one of the caves, leaving 1,054 that were found in more than one cave, including 109 found in all six (Fig. 3A, Supplemental Table S3).

To determine if these differences were significant, PCoA and ANOSIM analyses were performed. PCoA showed a noticeable delineation between speleothem and sediment OTU but not between caves, suggesting the microbiomes in the different caves are indistinct (Fig. 3B). Two-way ANOSIM analyses comparing the speleothem and sediment OTU between each cave demonstrated only small to moderate differences between them, and only $7 / 15$ of the comparisons had a significant $P$ value $\leq 0.05$. Surgener Cave stands out as the only one whose microbiome showed significant differences from the other five. An $R$-value from the combined samples from all caves provided a significant $R$-value of 0.37 , suggesting an overall low similarity of the microbiomes between the caves.

\section{Discussion}

Cave Microbiomes in a Temperate Environment Share Fewer than Expected OTU with the Surface Microbiome

A long-held assumption in cave ecology has been that cave microbiomes, representing a potential primary source of energy entering the food web, are composed of surface microbes and organic matter that have been transported in by flowing or dripping water, roots, or animal occupants (Laiz et al., 1999, Simon et al., 2003, Engel and Northup, 2008). The microbiomes of cave interiors have been studied for decades and an extensive list of troglobitic bacteria have been compiled (e.g., Tomcyzyk-Zak and Zielenkiewicz, 2016), yet comparisons between interior and exterior microbial communities are sparse. Most recently, two metabarcoding surveys of cave systems in arid regions of North America compared cave speleothem and microbial mat microbiomes to those found in surface soils (Ortiz et al., 2013, Lavoie et al., 2017). Both studies found very low overlap between subsurface and exterior microbiomes; $16 \%$ between speleothems in Kartchner Cavens, AZ and surface soil and $11.2 \%$ between lava cave microbial mats and surface soil. These studies provide evidence that the majority of cave microbes may be cave-adapted endemics and not dormant or physiologically suppressed surface microbes that have washed in.

We surveyed the prokaryotic microbiomes from speleothems and soil from six caves in the temperate Appalachian region of Southwest Virginia and compared them to surface soil microbiomes to test the following hypothesis: caves in 
Table 1. Relative amounts (\%) of prokaryotic phyla found in each sample type.

\begin{tabular}{|c|c|c|c|c|}
\hline Taxonomy & Surface Soil & Speleothems & Cave Sediment & Cave Specific \\
\hline \multicolumn{5}{|l|}{ Phylum } \\
\hline Actinobacteria & 22.75 & 21.91 & 19.47 & 10.16 \\
\hline Proteobacteria & 14.29 & 16.05 & 14.21 & 12.97 \\
\hline Acidobacteria & 11.97 & 12.15 & 9.85 & 5.47 \\
\hline Planctomycetes & 8.22 & 6.07 & 7.82 & 6.56 \\
\hline Gemmatimonadetes & 7.26 & 7.16 & 7.52 & 5.63 \\
\hline Armatimonadetes & 4.15 & 4.12 & 3.68 & 2.81 \\
\hline Bacteroidetes & 3.03 & 3.90 & 3.61 & 3.44 \\
\hline Chloroflexi & 3.03 & 3.04 & 3.08 & 2.81 \\
\hline TM7 & 1.92 & 1.52 & 1.95 & 2.81 \\
\hline BRC1 & 2.00 & 1.52 & 1.73 & 1.25 \\
\hline OD1 & 1.44 & 1.52 & 1.58 & 2.34 \\
\hline Tenericutes & 1.68 & 0.22 & 1.13 & nd \\
\hline Verrucomicrobia & 1.12 & 1.52 & 0.98 & 0.94 \\
\hline Chlamydiae & 0.48 & 0.65 & 0.75 & 0.94 \\
\hline Cyanobacteria & 0.72 & 0.43 & 0.53 & 0.47 \\
\hline GN04 & 0.16 & 0.87 & 0.68 & 1.41 \\
\hline WS3 & 0.56 & 0.65 & 0.68 & 0.63 \\
\hline Nitrospirae & 0.32 & nd & 0.45 & 0.78 \\
\hline OP3 & 0.48 & 0.43 & 0.45 & 0.47 \\
\hline Firmicutes & nd & 0.87 & 0.30 & 0.94 \\
\hline OP11 & 0.16 & 0.43 & 0.15 & 0.47 \\
\hline TM6 & 0.40 & nd & 0.30 & nd \\
\hline GOUTA4 & 0.08 & 0.22 & 0.15 & 0.31 \\
\hline AD3 & 0.08 & nd & 0.08 & 0.16 \\
\hline NC10 & nd & nd & 0.15 & 0.31 \\
\hline Chlorobi & 0.08 & nd & 0.08 & nd \\
\hline Fibrobacteres & 0.08 & nd & nd & nd \\
\hline GN02 & 0.08 & nd & nd & nd \\
\hline \multicolumn{5}{|l|}{ Archaea } \\
\hline Parvarchaeota & 0.88 & 1.30 & 2.26 & 4.53 \\
\hline Crenarchaeota & nd & 0.22 & nd & 0.16 \\
\hline \multicolumn{5}{|l|}{ Unassigned } \\
\hline$\cdots$ & 12.61 & 13.23 & 16.39 & 30.31 \\
\hline
\end{tabular}

a temperate environment would share a larger number of microbes with the surface than caves in an arid environment, based on the assumption that more surface microbes would enter caves in an environment with regular year-round rainfall than caves in arid environments that receive seasonal rainfall.

The Ortiz et al., (2013) and Lavoie et al., (2017) studies compared the microbiomes of cave speleothems to surface soils. When we compared speleothem+damp ceiling samples with surface soil we found a $21.4 \%$ overlap, which demonstrated a higher incidence of overlapping microbes than was seen in the arid environments, but the overlap was still relatively low, suggesting over $78 \%$ of the microbes living on speleothems and ceilings were cave-adapted. Based on these observations, we reject our first hypothesis.

We also included cave sediment microbes in our study and found that these had an OTU overlap of $53.8 \%$, much higher than speleothems but still lower than anticipated if surface soil and its accompanying microbes were being hydraulically transported into, and subsequently colonizing, caves. All six caves have perpetually-running streams that are presumably fed from a combination of surface water and groundwater sources. We believed this water could serve as a pathway for the entrance of microbes into the caves and that they would be more likely to be found in cave sediments than on speleothems. There was a much larger overlap between cave sediments and surface soils but it was still lower than expected, with a little over half the OTU found in both locations. These data suggest cave sediment microbiomes harbor large numbers of unique species and strains of microbes able to survive and propagate in the nutrient-poor subsurface environment, and that infiltrating groundwater and sinking streams are only minor contributing factors. Thus, we cannot comfortably reject or maintain our hypotheses without further comparisons.

\section{The Microbiomes Among Caves are Similar}

A comparison of three geographically distinct European caves discovered 474 distinct 165 OTU using a clonal approach and found very similar microbial profiles, leading the authors to posit that limestone caves harbor similar microbiota (Porca et al., 2012). In contrast, microbiome surveys of individual speleothems and microbial mats have demonstrated these features can have unique microbiomes, with no correlation between the number of shared OTU and 
A.

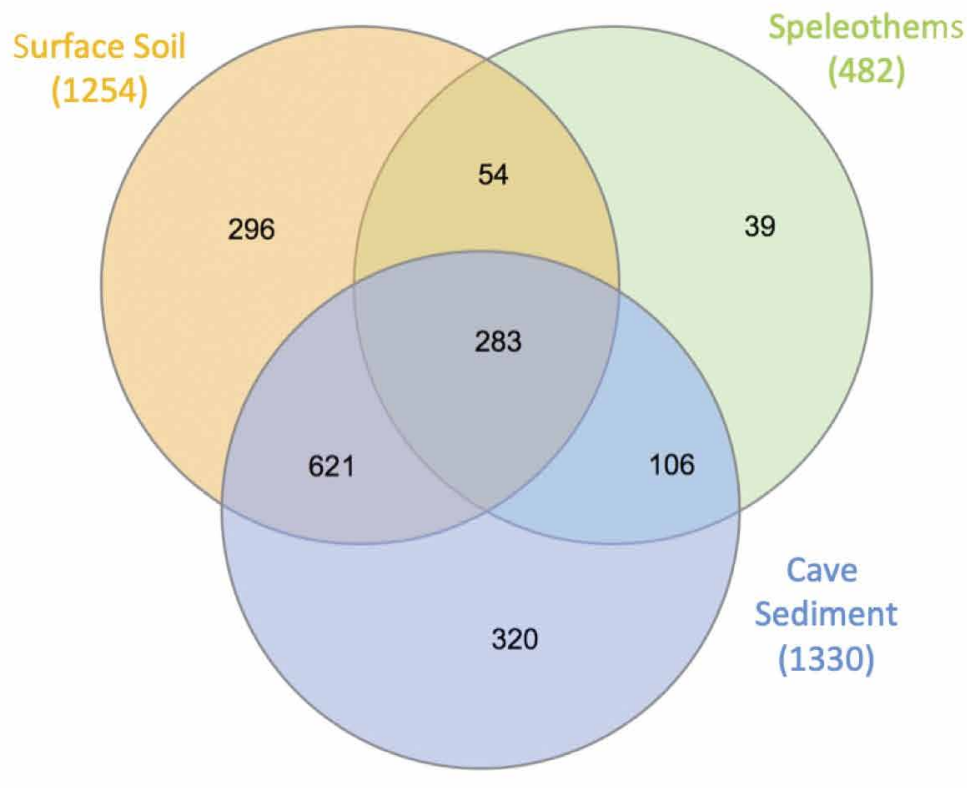

B.

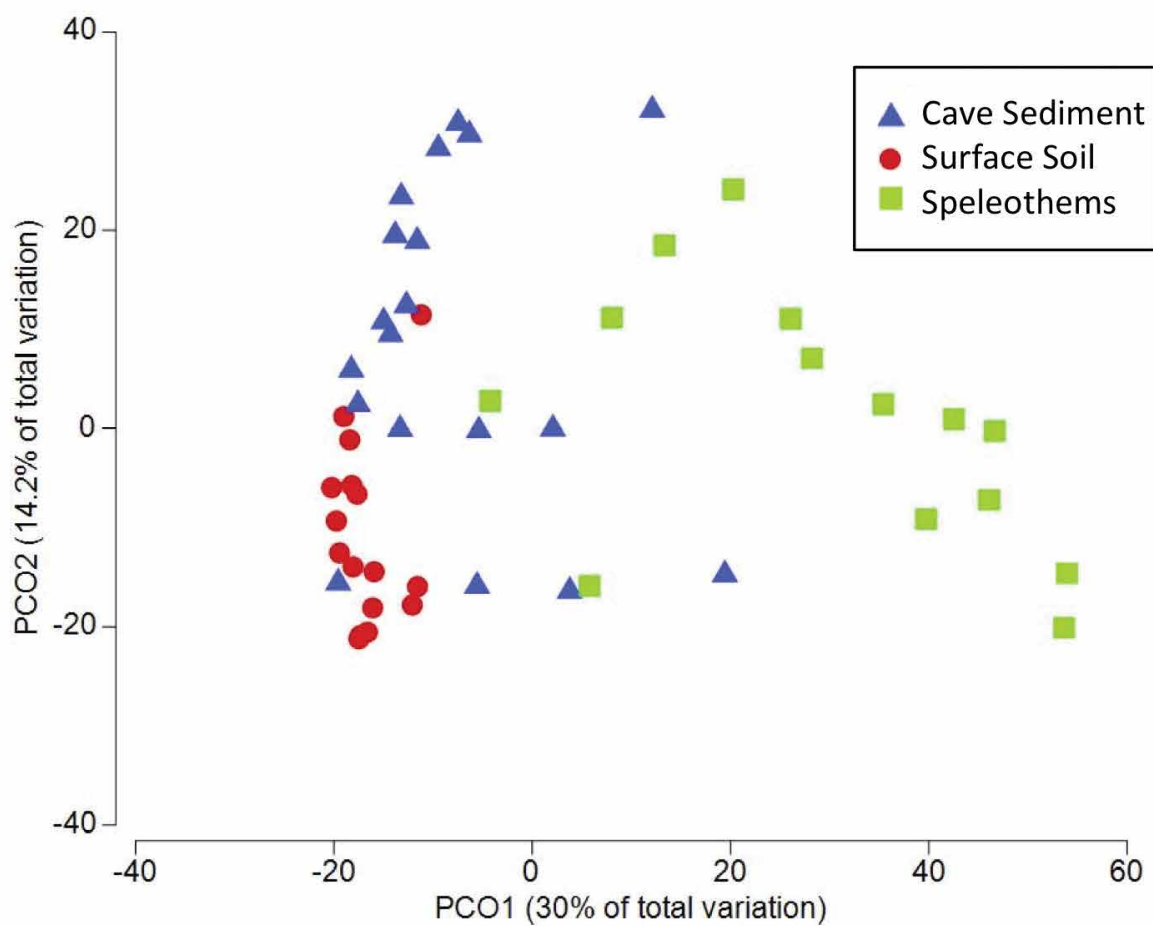

Figure 2. Comparisons of the prokaryotic microbiomes of cave interiors to surface soil. (A) Venn diagram showing the numbers of unique operational taxonomic units (OTU) shared between interior sample types and exterior soil. (B) Principle coordinates plot demonstrating the similarities between the sample types. Each symbol represents an independent sample from one of the six sample sites. (1) 2013): Actinobacteria, Proteobacteria, Acidobacteria, Planctomycetes, Gemmatimonadetes, and Bacteroidetes. We did, however, uncover cave-specific taxa from two phyla not mentioned in previous studies: Armatimonadetes, and Parvarchaeota. proximity (Legatzki, 2011,2012; Ortiz et al., 2013; Lavoie et al., 2017). These studies showed that a highly diverse microbial community could exist upon a single cave formation, and that community structure was variable from formation to formation, suggesting that microbial community composition may be site-specific at some scale.

Our second hypothesis, individual caves within an ecosystem would have insignificantly different microbiomes, was formed based on the observation that variation between speleothems and rock surfaces within caves is comparable to that found between geographically diverse caves (Ortiz et al., 2013). Considering the observations of Porca et al. (2012), we presumed the OTU found within the six sampled caves would be insignificantly different from cave to cave. The caves we sampled are located in different watersheds, but within a radius of $40 \mathrm{~km}$, and four of the caves (Surgener, Gallohan 1, Gallohan 2, and Smith-Milk) represent separate entrances into a presumed single cave system. PCoA analyses demonstrated differences between cave samples, but according to ANOSIM, these were small to moderate differences, suggesting that the cave microbiomes are not unique to individual caves, which supports the observations of Porca et al. (2012), as well as our second hypothesis.

Cave-specific Microbial Taxa Unique to this Metagenomic Survey

The predominant cave-specific microbial phyla found in our study (Table 1) are similar 
A

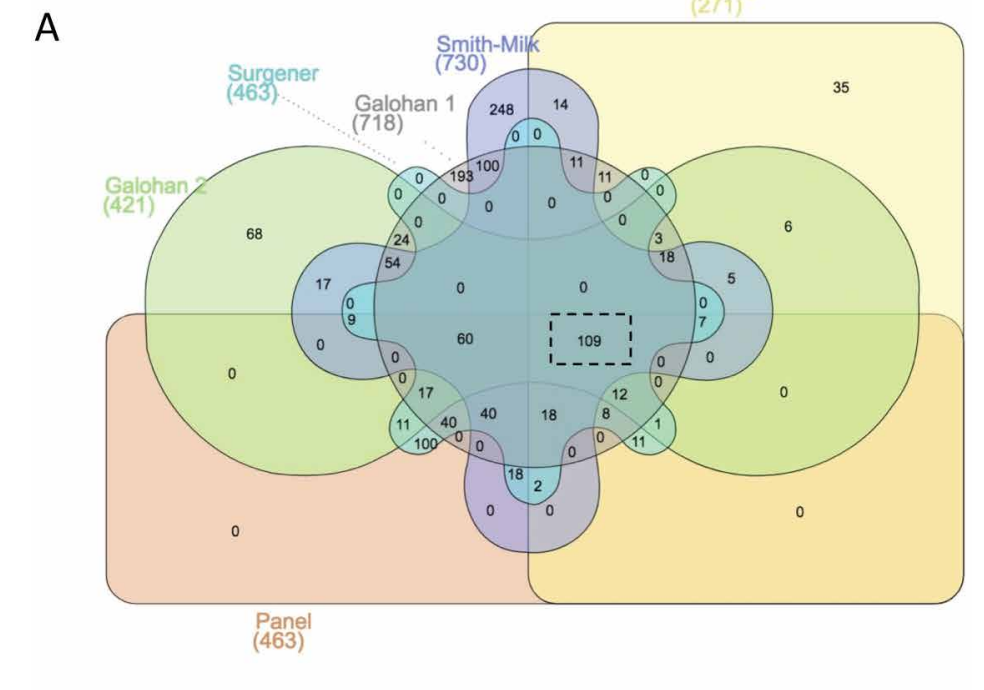

B

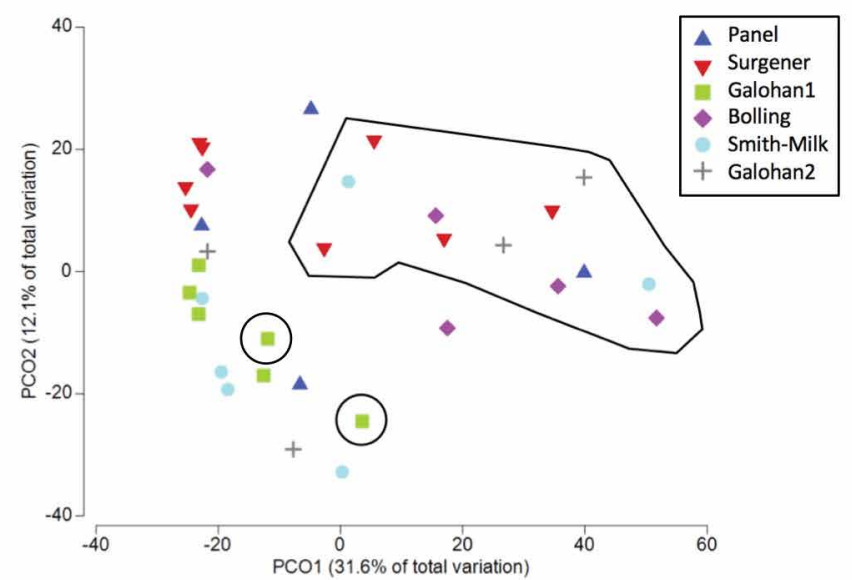

Figure 3. Comparisons of the microbiomes of the six caves sampled for this study. (A) Six-way Venn diagram showing the numbers of unique operational taxonomic units (OTU) shared between each cave. Speleothem and cave sediment OTU were combined for each cave. The diagram was generated using InteractiVenn (Heberle et al., 2015) (B) Principle coordinates plot demonstrating the similarities between the microbiomes of each cave. Each symbol represents an independent sample from one of the six caves. The speleothem samples are circled or enclosed within a freeform shape. The non-enclosed symbols represent cave sediment samples. ment with regular year-round rainfall. This study also demonstrates that the interiors of the six caves hosted relatively uniform microbiomes, suggesting these microbes have adapted to the cave environment. Mechanisms for communication between caves and the surface and between cave systems in the southern Appalachians are poorly understood and are presumably related to the complex geologic and evolutionary history of the region. These results suggest that further exploration of these ecosystems is warranted and could uncover unique microbiomes.

\section{Acknowledgements}

The authors thank Adam Jones, Layton Gardner, and Tim McDonald for their help with sampling, Theresa L. Brown for reviewing the manuscript, the Natural Tunnel State Park and the Virginia Department of Conservation and Recreation for generous access to the sample sites. The GCAT-SEEK workshop and sequence data were supported by a grant to Juniata College from the Howard Hughes Medical Institute (http://www.hhmi.org) through the Precollege and Undergraduate Science Education Program, the National Science Foundation (www.nsf.gov), NSF award DBI1248096. $16 S$ metagenomic surveys from a wide variety of environments including hot springs and geothermal soils soils (Dunbar et al., 2002; Lipson and Schmidt 2004), and freshwater (Crump and Hobbie 2005; Urbach et al., 2001; Wu et al., 2007). Three species from this phylum have been cultured and described as aerobic chemoheterotrophs. Armatimonas rosea, was isolated from the rhizophere of a reed from in a freshwater lake in Japan (Tamaki et al., 2011); Fimbriimonas ginsengisoli was collected from ginseng field soil in South Korea (Im et al., 2012); and, Chthonomonas calidirosea was cultured from geothermally-heated soil in New Zealand (Lee et al., 2011). Fifty-eight distinct cave-specific Armatimonadetes OTU were identified in our study and sixteen were identifiable as the genera Armatimonas and Fimbriimonas (Supplemental Table 3). covered in acid mine drainage (AMD) of Iron Mountain in Richmond, CA, USA, and are among the smallest known cells (Comolli et al., 2009; Baker et al., 2006). A survey of Parvarchaeota from 39 AMD and hot springs sites from around the world found them residing only in AMD sites. Follow-up culture plus genome analyses from the same study suggested they are iron-oxidizing anaerobes that must scavenge amino acids and nucleotides from the environment or other organisms (Chen et al., 2018).

Even though species from Armatimonadetes have not been reported from caves, this habitat is consistent with previous descriptions since they can live in a wide range of habitats. This is not the case for Parvarchaeota since the damp karst cave features do not offer a habitat similar to AMD.

\section{Conclusions}

Our data demonstrate a consistent distinction between the community structures of cave-dwelling microbes and surface microbes in a temperate environ-

Armatimonadetes is a phylum first defined from 
Table 2. One-way ANOSIM values comparing each sample type.

\begin{tabular}{|c|c|c|c|c|c|c|c|c|}
\hline \multirow[b]{2}{*}{ Cave } & \multicolumn{2}{|c|}{$\begin{array}{l}\text { Speleothem vs. } \\
\text { Cave Sediment }\end{array}$} & \multicolumn{2}{|c|}{$\begin{array}{c}\text { Cave Sediment vs. } \\
\text { Surface Soil }\end{array}$} & \multicolumn{2}{|c|}{$\begin{array}{l}\text { Speleothem vs. } \\
\text { Surface Soil }\end{array}$} & \multicolumn{2}{|c|}{$\begin{array}{l}\text { All Interior vs. } \\
\text { Surface Soil }\end{array}$} \\
\hline & $R$-value & $P$-value & $R$-value & $P$-value & $R$-value & $P$-value & $R$-value & $P$-value \\
\hline Surgener & 0.889 & 0.029 & 0.889 & 0.029 & 0.771 & 0.029 & 0.677 & 0.001 \\
\hline Gallohan 1 & 0.833 & 0.1 & 0.537 & 0.029 & 0.714 & 0.067 & 0.615 & 0.001 \\
\hline Gallohan 2 & 1 & 0.1 & 0.583 & 0.1 & 1 & 0.333 & 0.725 & 0.01 \\
\hline Smith-Milk & 0.75 & 0.1 & 0.093 & 0.314 & 0.607 & 0.133 & 0 & 0.536 \\
\hline Bolling & 0.917 & 0.01 & 0 & 0.667 & 0.583 & 0.01 & 0.5 & 0.076 \\
\hline Panel & 1 & 0.333 & 0 & 0.7 & 1 & 0.25 & 0.409 & 0.167 \\
\hline All ${ }^{\mathrm{a}}$ & 0.726 & 0.001 & 0.23 & 0.001 & 0.509 & 0.001 & 0.43 & 0.001 \\
\hline
\end{tabular}

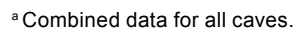

Table 3. Two-way ANOSIM TESTS cave vs cave (speleothems and sediment).

\begin{tabular}{|c|c|c|c|c|c|c|c|c|c|c|}
\hline \multirow[b]{2}{*}{ Cave } & \multicolumn{2}{|c|}{ Panel } & \multicolumn{2}{|c|}{ Bolling } & \multicolumn{2}{|c|}{ Smith-Milk } & \multicolumn{2}{|c|}{ Gallohan 2} & \multicolumn{2}{|c|}{ Gallohan 1} \\
\hline & $R$-value & P-value & $R$-value & $P$-value & $R$-value & $P$-value & $R$-value & $P$-value & $R$-value & $P$-value \\
\hline Surgener & 0.57 & $(0.011)$ & 0.50 & $(.019)$ & 0.558 & $(0.06)$ & 0.607 & $(.04)$ & 0.494 & -0.002 \\
\hline Gallohan 1 & 0.343 & $(0.038)$ & 0.586 & $(.027)$ & 0.125 & $(0.152)$ & 0.392 & $(0.089)$ & $\ldots$ & $\ldots$ \\
\hline Gallohan 2 & 0 & $(0.60)$ & 0.403 & $(0.067)$ & 0 & $(0.778)$ & $\cdots$ & $\cdots$ & $\cdots$ & $\cdots$ \\
\hline Smith-Milk & 0.185 & $(0.162)$ & 0.396 & $(0.080)$ & $\cdots$ & $\cdots$ & $\cdots$ & $\cdots$ & $\cdots$ & $\cdots$ \\
\hline Bolling & 0.048 & $(0.425)$ & $\cdots$ & $\ldots$ & $\ldots$ & $\ldots$ & $\ldots$ & $\ldots$ & $\ldots$ & $\ldots$ \\
\hline Alla & 0.37 & $(.002)$ & $\cdots$ & $\cdots$ & $\cdots$ & $\cdots$ & $\cdots$ & $\cdots$ & $\cdots$ & $\cdots$ \\
\hline
\end{tabular}

${ }^{\mathrm{a}}$ Combined data for all caves.

\section{References}

Baker, B.J., Tyson, G.W., Webb, R.I., Flanagan, J., Hugenholtz, P., and Banfield, J.F., 2006, Lineages of acidophilic Archaea revealed by community genomic analysis: Science, v. 314, p. 1933-1935. https://doi.10.1126/science.1132690.

Barton, H.A. and Jurado, V., 2007, What's up down there? Microbial diversity in caves: Microbe, v. 2, p.132-138.

Barton, H.A. and Northup, D.E., 2007, Geomicrobiology in cave environments: Past, current and future perspectives: Journal of Cave and Karst Studies, v. 69, p. 163-178.

Barton, H.A., Taylor, M.R., and Pace, N.R., 2004, Molecular phylogenetic analysis of a bacterial community in an oligotrophic cave environment: Geomicrobiology Journal, v. 21, p. 11-20. https://doi.10.1080/01490450490253428.

Barton, H.A., Taylor, N.M., Kreate, M.P., Springer, A.C., Oehrle, S.A., and Bertog, J.L., 2007, The impact of host rock geochemistry on bacterial community structure in oligotrophic cave environments: International Journal of Speleology, v. 36, p. 93-104. https://doi.10.5038/1827806X.36.2.5.

Brent, W.B., 1963, Geology of the Clinchport Quadrangle Virginia: Virginia Division of Mineral Resources Report of Investigations 5, 47 p.

Caporaso, J. G., Kuczynski, J., Stombaugh, J., Bittinger, K., Bushman, F.D., Costello, E.K., Fierer, N., Peña, A.G., Goodrich, J.K., Gordon, J.I., Huttley, G.A., Kelley, S.T., Knights, D., Koenig, J.E., Ley, R.E., Lozupone, C.A., McDonald, D., Muegge, B.D., Pirrung, M., Reeder, J., Sevenisky, J.R., Turnbaugh, P.J., Walters, W.A., Widmann, J., Yatsunenko, T., Zaneveld, J., and Knight, R., 2010, QIIME allows analysis of high-throughput community sequencing data: Nature Methods, v. 7, p. 335-336. https://doi.10.1038/nmeth.f.303.

Caporaso, J.G., Lauber, C.L., Walters, W.A., Berg-Lyons, D., Lozupone, C.A., Turnbaugh, P.J., Fierer, N., and Knight, R., 2011, Global patterns of 16S rRNA diversity at a depth of millions of sequences per sample: Proceedings of the National Academy of Science USA, v. 108 Suppl 1, p. 4516-4522. https://doi.10.1073/pnas.1000080107.

Caumartin, V., 1963, Review of the microbiology of underground environments: National Speleological Society Bulletin, v. 25, p. 1-14.

Chao, A. and Chiu, C. H., 2016, Species richness: estimation and comparison: Wiley StatsRef: Statistics Reference Online, p. 1-26. https:// doi.10.1002/9781118445112.stat03432.pub2.

Clarke, K.R. and Gorley, R.N., 2015, PRIMER v7: User Manual/Tutorial. PRIMER-E, Plymouth. (Plymouth Routines In Multivariate Ecological Research), 3 Meadow View, Lutton, Ivybridge, Devon PL21 9RH, United Kingdom. 214 p.

Comolli, L.R., Baker, B.J., Downing, K.H., Siegerist, C.E., and Banfield, J.F., 2009, Three-dimensional analysis of the structure and ecology of a novel, ultra-small archaeon: ISME Journal, v. 3, p. 159-167. https://doi.10.1038/ismej.2008.99.

Crump, B. C. and Hobbie, J. E., 2005, Synchrony and seasonality in bacterioplankton communities of two temperate rivers: Limnology and Oceanography, v. 50, p. 1718-1729, DOI.org/10.4319/lo.2005.50.6.1718.

De Mandal, S., Chatterjee, R., and Kumar, N.S., 2017, Dominant bacterial phyla in caves and their predicted functional roles in C and N cycle: BMC Microbiology, v. 17, p. 90-99. https://doi. 10.1186/s12866-017-1002-x.

DeSantis,T.Z., Hugenholtz, P., Larsen, N., Rojas, M., Brodie, E.L., Keller, K., Huber, T., Dalevi, D., Hu, P., and Andersen, G.L., 2006, Greengenes, a chimera-checked 16S rRNA gene database and workbench compatible with ARB: Applied and Environmental Microbiology, v. 72, p. 5069-5072. https://doi.10.1128/AEM.03006-05. 
Dorigo, U., Volatier, L., and Humbert, J.F., 2005, Molecular approaches to the assessment of biodiversity in aquatic microbial communities: Water Research, v. 39, p. 2207-2218. https://doi.10.1016/j.watres.2005.04.007.

Dunbar, J., Barns, S. M., Ticknor, L. O., and Kuske, C. R., 2002, Empirical and theoretical bacterial diversity in four Arizona soils: Applied and Environmental Microbiology, v. 68, p. 3035-3045. https://doi.10.1128/AEM.68.6.3035-3045.2002.

Edgar, R.C., 2010, Search and clustering orders of magnitude faster than BLAST: Bioinformatics, v. 26, p. 2460-2461. https://doi.10.1093/bioinformatics/btq461.

Engel, A.S., Stern, L.A., and Bennett, P.C., 2004, Microbial contributions to cave formation: new insights into sulfuric acid speleogenesis: Geology, v. 32, p. 369-372. https://doi.10.1130/G20288.1.

Engel, A.S., and Northup, D.E., 2008, Caves and karst as models for advancing microbial sciences, in Martin, J.B., White, W.B., eds., Frontiers of Karst Research: Proceedings and Recommendations of the Workshop Held May 3 through 5, 2007 in San Antonio, Texas, USA. Leesburg, Va.: Karst Waters Institute, Inc., p. 37-48.

Handelsman, J., 2004, Metagenomics:Application of genomics to uncultured microorganisms: Microbiology and Molecular Biology Reviews, v. 68, p. 669-685. https://doi.10.1128/MMBR.68.4.669-685.2004.

Heberle, H., Meirelles, G.V., da Silva, F.R., Telles, G.P., Minghim, R., 2015, InteractiVenn: a web-based tool for the analysis of sets through Venn diagrams. BMC Bioinformatics, v. 16, p. 169. https://doi.10.1186/s12859-015-0611-3.

Hugenholtz, P., Pitulle, C., Hershberger, K.L. , and Pace N.R., 1998, Novel division level bacterial diversity in a Yellowstone hot spring: Journal of Bacteriology, v. 180, p. 366-376.

Im, W-T., Hu, A-Y., Kim, K-H., Rhee, S-K., Meng, H., Lee, S-T., and Quan, Z-X. 2012, Description of Fimbriimonas ginsengisoli gen. nov., sp. nov. within the Fimbriimonadia class nov., of the phylum Armatimonadetes: Antonie van Leeuwenhoek, v. 102, p. 307-317. https://doi.0.1007/ s10482-012-9739-6.

Laiz, L., Groth, I., Gonzalez, I., and Saiz-Jimenez, C., 1999, Microbiological study of the dripping waters in Altamira Cave (Santillana del Mar, Spain): Journal of Microbiological Methods, v. 36, p. 129-138. https://doi.10.1016/S0167-7012(99)00018-4.

Lavoie, K.H., Winter, A.S., Read, K.J.H., Hughes, E.M., Spilde, M.N., and Northup, D.E., 2017, Comparison of bacterial communities from lava cave microbial mats to overlying surface soils from Lava Beds National Monument, USA: PLoS One, v. 12, e0169339. https://doi.10.1371/journal.pone.0169339

Lee, K.C-Y., Dunfield, P.F., Morgan, X.C., Crowe, M.A., Houghton, K.M., Vyssotski, M., Ryan, J.L.J., Lagutin, K., McDonald, I.R., and Stott, M.B., 2011, Chthonomonas calidirosea gen. nov., sp. nov., an aerobic, pigmented, thermophilic micro-organism of a novel bacterial class, Chthonomonadetes classis nov., of the newly described phylum Armatimonadetes originally designated candidate division OP10: International Journal of Systematic and Evolutionary Microbiology, v. 61, p. 2482-2490. https://doi.10.1099/ijs.0.027235-0.

Legatzki, A., Ortiz, M., Neilson, J.W., Dominguez, S., Anderson, G.L., Toomey, R.S., Pryor, B.M., Pierson, L.S., and Maier, R.M., 2011, Bacterial and archaeal community structure of two adjacent calcite speleothems in Kartchner Caverns, AZ, USA: Geomicrobiology Journal, v. 28, p. 99-117. https://doi.10.1080/01490451003738465.

Legatzki, A., Ortiz, M., Neilson, J.W., Casvant, R.R., Palmer, M.W., Rasmussen, C., Pryor, B.M., Pierson, L.S., and Maier, R.M., 2012, Factors influencing observed variations in the structure of bacterial communities on calcite formations in Kartchner Caverns, Ariz., USA: Geomicrobiology Journal, v. 29, p. 422-434. https://doi.10.1080/01490451.2011.581326.

Lipson, D.A. and Schmidt, S.K., 2004, Seasonal changes in an alpine soil bacterial community in the Colorado rocky mountains: Applied and Environmental Microbiology, v. 70, p. 2867-2879. https://doi.10.1128/aem.70.5.2867-2879.2004.

Mendoza, M.L.Z., Lundberg, J., Ivarsson, M., Campos, P., Nylander, J.A.A., Sallstedt, T., and Dalen, L., 2016, Metagenomic analysis from the interior of a speleothem in Tjuv-Ante's cave, Northern Sweden: PLoS One, v. 11, e0161577. https://doi.10.1371/journal.pone.0151577.

Miller, R.L. and Brosge. W.P., 1954, Geology and Oil Resources of the Jonesville District, Lee County, Virginia: USGS Geological Survey Bulletin No.99, 210 p.

Northup, D.E. and Lavoie, K.H., 2001, Geomicrobiology of caves: a review: Geomicrobiology Journal, v. 18, p.199-222. https:// doi.10.1080/01490450152467750.

Oksanen, J., Guillaume-Blanchet F., Friendly, M., Kindt, R., Legendre, P., McGlinn, D., Minchin, P.R., O'Hara, R.B., Simpson, G.L., Solymos, P., Henry, M., Stevens, H., Szoecs, and E., Wagner, H., 2018, Vegan: Community Ecology Package, R package version 2.5-2. https:// CRAN.R-project.org/package=vegan.

Ortiz, M., Neilson, J.W., Nelson, W.M., Legatzki, A., Byrne, A., Yu, Y., Wing, R.A., Soderlund, C.A., Pryor, B.M., Pierson, L.S. $3^{\text {rd }}$, and Maier, R.M., 2013, Profiling bacterial diversity and taxonomic composition on speleothem surfaces in Kartchner Caverns, Ariz.: Microbial Ecology, v. 65, p. 371-383. https://doi.10.1007/s00248-012-0143-6.

Ortiz, M., Legatzki, A., Neilson, J.W., Fryslie, B., Nelson, W.M., Wing, R.A., Soderlund, C.A., Pryor, B.M., and Maier, R.M., 2014, Making a living while starving in the dark: metagenomic insights into the energy dynamics of a carbonate cave: ISME Journal, v. 8, p. 478-491. https:// doi.10.1038/ismej.2013.159.

Pielou, E.C., 1969, An Introduction to Mathematical Ecology: Wiley, NY. https://doi.10.1002/bimj.19710130308.

Porca, E., Jurado, V., Zgur-Bertok, D., Saiz-Jimenez, C., and Pasic, L., 2012, Comparative analysis of yellow microbial communities growing on the walls of geographically distinct caves indicates a common core of microorganisms involved in their formation: FEMS Microbiology Ecology, v. 81, p. 255-266. https://doi.10.1111/j.1574-6941.2012.01383.x.

R Core Team 2018, R: A language and environment for statistical computing. https://www.R-project.org.

Simon, K.S., Benfield, E.F., and Macko, S.A., 2003, Food web structure and the role of epilithic biofilms in cave streams. Ecology. V. 84 , p. 2395-2406, https://doi.10.1890/02-334.

Smith, B. and Wilson, J.B., 1996, A consumer's guide to evenness indices: OIKOS, v. 76, p. 70-82, www.jstor.org/stable/pdf/3545749.pdf

Stott M. B., Crowe, M.A., Mountain, B.W., Smirnova, A.V., Hou, S., Alam, M., and Dunfield P. F., 2008, Isolation of novel bacteria, including a candidate division, from geothermal soils in New Zealand: Environmental Microbiology, v. 10, p. 2030-2041. https://doi.10.1111 /j.1462-2920.2008.01621.

Tamaki, H., Tanaka, Y., Matsuzawa, H., Muramatsu, M., Meng, X.Y., Hanada, S., Mori, K., and Kamagata, Y., 2011, Armatimonas rosea gen. nov., sp nov., of a novel bacterial phylum, Armatimonadetes phyl. nov., formally called the candidate phylum OP10: International Journal of Systematic and Evolutionary Microbiology, v. 61, p. 1442-1447. https://doi.10.1099/ijs.0.025643-0.

Tomczyk-Żak, K. and Zielenkiewicz, U., 2016, Microbial diversity in caves: Geomicrobiology Journal, v. 33, p. 20-38. https://doi.10.1080/01490 451.2014.1003341.

Torsvik, V. and Øvreås, L., 2002, Microbial diversity and function in soil: from genes to ecosystems: Current Opinion in Microbiology, v. 5, p.240-245. https://doi.10.1016/S1369-5274(02)00324-7. 
Urbach E., Vergin K. L., Young L. , Morse A. , Larson G. L. , and Giovannoni S. J., 2001, Unusual bacterioplankton community structure in ultra-oligotrophic Crater Lake: Limnololgy and Oceanography, v. 46, p. 557-572. https://doi.10.4319/lo.2001.46.3.0557.

Vardeh, D.P., Woodhouse, J.N., and Neilan, B.A. 2018, Microbial diversity of speleothems in two southeast Australian limestone cave arches: Journal of Cave and Karst Studies, v. 80, p. 121-132. https://doi.10.4311/2017MB0119.

Wang, Q., Garrity, G.M., Tiedje, J.M., and Cole, J.R., 2007, Naïve Bayesian classifier for rapid assignment of rRNA sequences into the new bacterial taxonomy: Applied and Environmental Microbiology, v. 73, p. 5261-5267. https://doi.10.1128/AEM.00062-07.

Wooley, J.C., Godzik, A., and Friedberg, I., 2010, A primer on metagenomics: PLoS Computational Biology,. e10000667. https://doi.10.1371/journal.pcbi.1000667.

Wu, X., Xi, W., Ye, W., and Yang, H.,2007, Bacterial community composition of a shallow hypertrophic freshwater lake in China, revealed by $16 \mathrm{~S}$ rRNA gene sequences: FEMS Microbiology Ecology, v. 61, p. 85-96, https://doi.10.1111/j.1574-6941.2007.00326.x. 